\title{
EQUiLIBRIUM
}

Quarterly Journal of Economics and Economic Policy

2016 VOLUME 11 ISSUE 3, September

p-ISSN 1689-765X, e-ISSN 2353-3293

www.economic-policy.pl

Semenenko, I. (2016). Energy Security of Ukraine in the Context of Its Sustainable Development. Equilibrium. Quarterly Journal of Economics and Economic Policy, 11(3), 537-555. DOI: http://dx.doi.org/10.12775/EQUIL.2016.024

Inna Semenenko*

Volodymyr Dahl East Ukrainian National University, Ukraine

\section{Energy Security of Ukraine in the Context of Its Sustainable Development}

JEL Classification: $F 5 ; O 20 ; Q 01 ; Q 4 ; Q 5$

Keywords: energy security; fuel and energy resources; sustainable development; energy efficiency; energy consumption

\begin{abstract}
Energy security is an important issue for Ukraine's sustainable development. The main goal of the article is to show the state of energy security of Ukraine, analyze its tendencies and challenges, reveal the impact of energy security on sustainable development of a country. The state of the energy security of Ukraine was analyzed with the help of data collection, processing and analysis. Data was taken from State Statistics Service of Ukraine, Ministry of Energetics and Coal Industry of Ukraine, other sources, and analyzed with the help of tools of statistics and economic analysis.

Ukraine, being a developing country and experiencing war, political and economic crisis, struggles for energy security support. The present state of energy availability and consumption in the country influences its sustainable development and political stability, and is a significant restraint in country's survival. Despite the fact that Ukraine has enough resources' deposits to provide itself with energy, it provides less than 50\% of own demands and is dependent on Russia's resources.

Production of energy in Ukraine is decreasing, but energy consumption remains high. Ukrainian industries are energy-wasteful and energy-inefficient; the country has the leading positions in energy intensity of GDP. The article shows the
\end{abstract}

(C) Copyright Institute of Economic Research

Date of submission: March 12, 2015; date of acceptance: April 6, 2016

* Contact: isemenenko@ukr.net, Volodymyr Dahl East Ukrainian National University, Prospect Tsentralny 59-A, Severodonetsk, Luhansk region, 93400, Ukraine 
relation of energy sources and energy security of Ukraine to sustainable development, reveals the dependency of the Ukrainian energy security, and indicates its main threats and ways out.

\section{Introduction}

Energy security is an important issue in development of every country, and is an important constituent of a country's overall security. Energy resources of a country represent all its various resources, which are available for industrial and household usage. Energy security and energy usage trends define the technological development of a country, influence its overall performance and reveal the level of its sustainable development. Ukraine, being a developing country and experiencing war and subsequent political and economic crisis at the moment, struggles for energy security support. The present state of energy availability and consumption in the country influences its sustainable development within the limits of all three constituents: economic, ecological and social. Besides, the political stability of the country's substantially depends on energy security as well. Thus, the problem of energy security in Ukraine may become a significant restraint in country's survival and development. Therefore, the main goal of the research is to show the state of energy security of Ukraine, analyze its tendencies and challenges, reveal the impact of energy security on sustainable development of a country.

\section{Research Methodology}

The state of the energy security of Ukraine was analyzed with the help of data collection, processing and analysis. Data was taken from State Statistics Service of Ukraine, Ministry of Energetics and Coal Industry of Ukraine, reports and researches of other governmental and local departments and NGOs, and analyzed with the help of tools of statistics and economic analysis.

Ukraine is a country, which has deposits of all kinds of fuel and energy resources (natural gas, oil, coal, beat, uranium and others). However, present resources' reserves and the amount of their extraction are not enough for providing Ukraine with the necessary amount of the fuel and energy, and thus do not guarantee the level of country's energy security (State Geological and Mineral Resources of Ukraine, n.d.). 


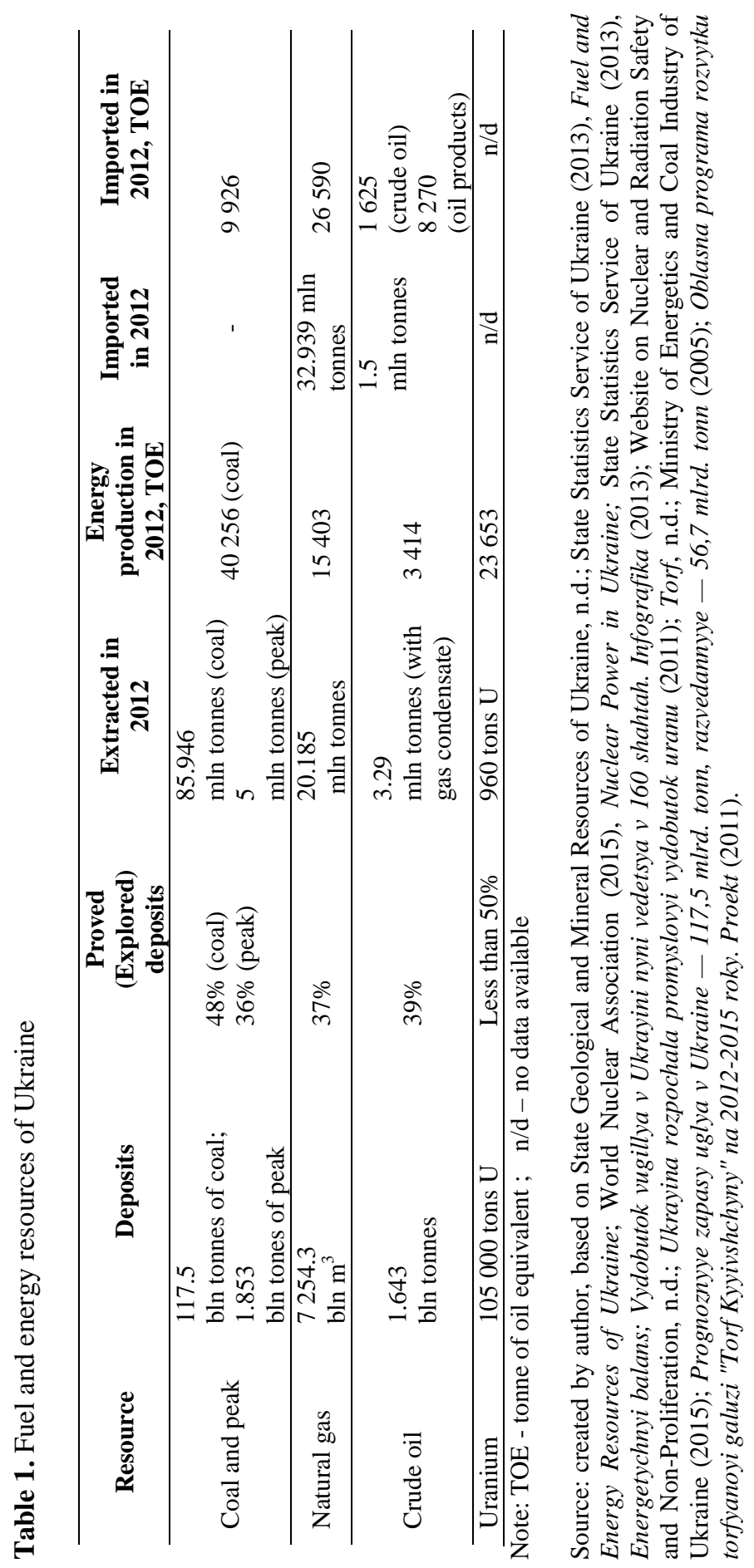




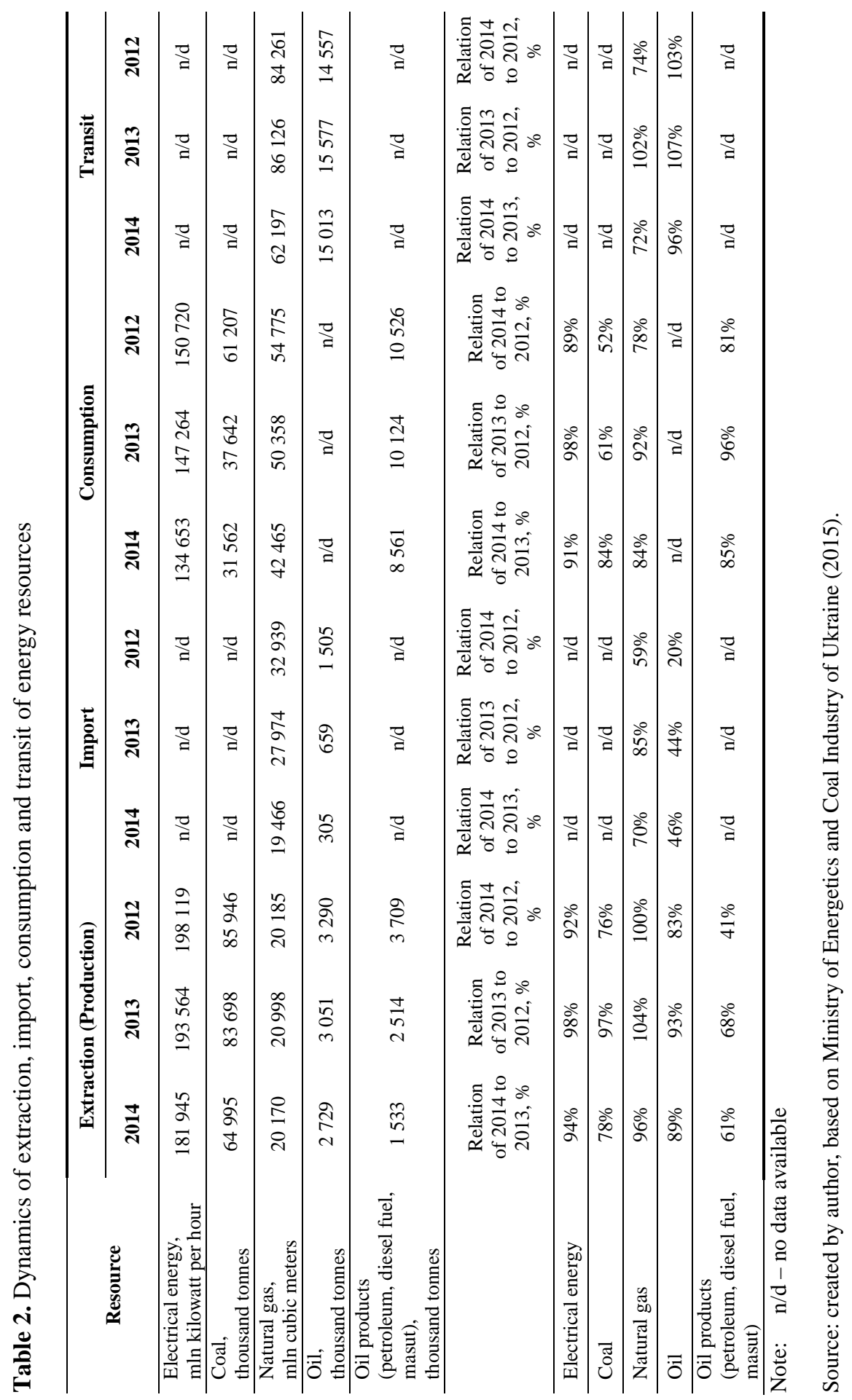


Ukraine provides only about $47 \%$ of its demands with own fuel and energy resources (State Geological and Mineral Resources of Ukraine, n.d.). The main resources, extracted by Ukraine, are coal and peat, natural gas, crude oil, uranium (State Geological and Mineral Resources of Ukraine, n.d.; State Statistics Service of Ukraine 2013, Fuel and Energy...) (Table 1 and 2).

The structure of final consumption of energy resources in Ukraine is presented on figure 1 .

Figure 1. Structure of final consumption of energy resources in Ukraine

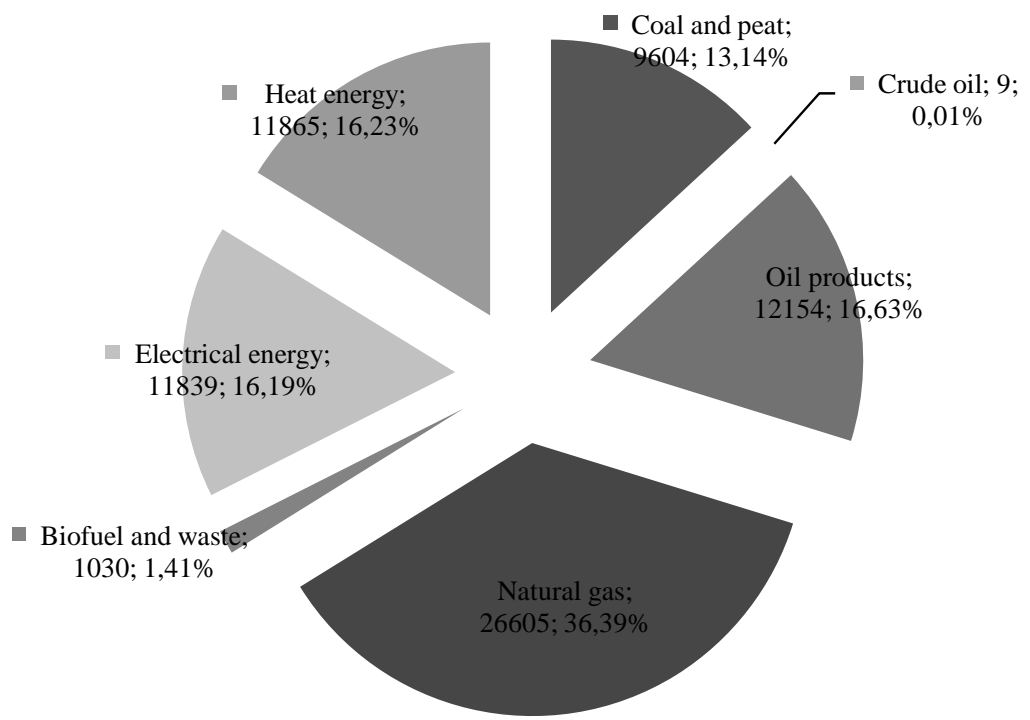

Note: the numbers, which represent consumption of resources, are measured in thousand TOE (tons of oil equivalent)

Source: created by author, based on State Statistics Service of Ukraine 2013, Fuel and Energy Resources of Ukraine.

Of all the consumed resources, natural gas has the leading position in final consumption (with share of $36.39 \%$ ), while crude oil is the least used source of energy (with share of only $0.01 \%$ ). Biofuel and waste remain not a popular energy source in Ukrainian consumption with a share of $1.41 \%$ in the total energy consumption. Oil products, coal and peat, heat energy and electrical energy have approximately the same shares, which vary from $13.14 \%$ to $16.63 \%$. It is necessary to note that atomic, hydro, wind and sun 


\section{2}

energy (which are listed as the sources, used in Ukraine, but are not represented on the graph at Figure 1) are used mostly for production of heat energy, and thus are not a source of energy for final consumption, but are resources for intermediate consumption.

Pattern of energy usage in 2012 (Figure 2) shows that industry and residential and household sector consume the majority of energy resources (33.98\% and $32.10 \%$ respectively). Agriculture, trade and services require minor energy costs. Transport consumed $15.66 \%$ of all energy resources (74\% of the "transport energy" was consumed by automobile transport). Trade and services required only $6.89 \%$ of all energy consumed in Ukraine. The share of agriculture and fishery was only $3 \%$, among which almost all the energy was consumed by agriculture with the exception of 11 thousands TOE (which is only $0.5 \%$ of all the energy consumed by this sector). Nonenergy usage includes usage of energy resources mainly as raw materials. Its share in total consuming of energy resources was 8.37\% in 2012 (State Statistics Service of Ukraine, 2013, Energetychnyi balans).

Figure 2. Pattern of energy usage in Ukraine in 2012

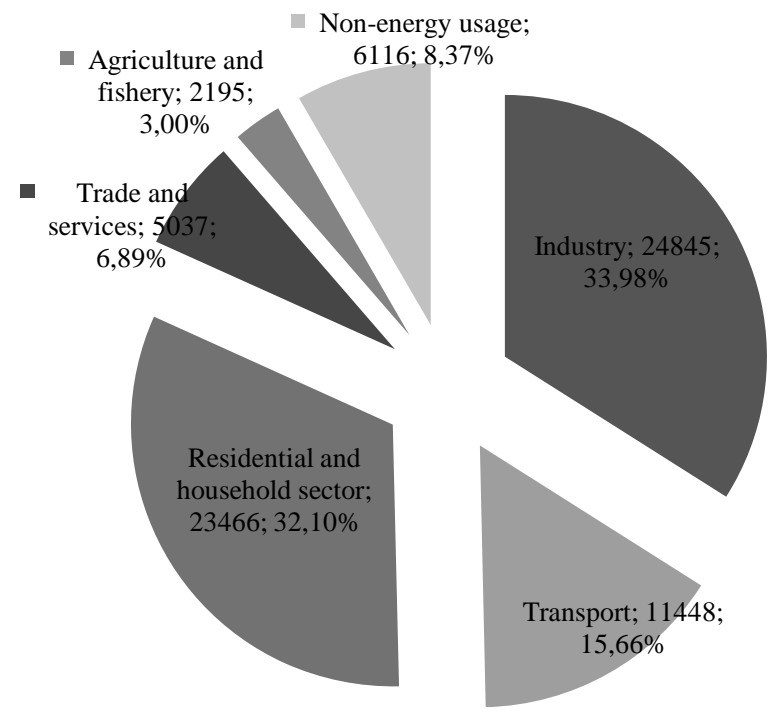

Note: the numbers, which represent consumption of resources, are measured in thousand TOE (tons of oil equivalent)

Source: created by author, using data in (State Statistics Service of Ukraine, 2013, Energetychnyi balans) 
Coal is the main energy resource of Ukraine, which significantly supports its energy security. Deposits of coal in Ukraine amount $7.5 \%$ of world deposits, placing the country among the top 5 countries with the largest coal deposits (after China, the USA, India and Russian Federation) (State Geological and Mineral Resources of Ukraine, n.d.). The amount of coal, extracted annually in Ukraine, makes about $1.5 \%$ of world extraction. Luhansk and Donetsk regions produce $70 \%$ of Ukrainian total coal (43\% and 27\% respectively) (Vydobutok vugillya..., 2013).

Production of coal in 2014 was $22 \%$ less than in 2013, and $24 \%$ less than in 2012. Such significant decrease can be explained by the antiterrorist operation, which started in 2014 in Luhansk and Donetsk regions of Ukraine and continues in 2015. The consumption of coal also decreased, however, the rate of such decrease differs from the rate of production decrease (16\% less in 2014 compared to 2013).

Natural gas remains an important energy source in Ukraine. However, the country cannot provide itself with the necessary energy. Russia is the main importer of gas into Ukraine. In 2013 Russia provided 25.8 bln cubic meters of imported gas (or 92\% of total imported gas) to Ukraine, which is nevertheless 15.1\% less than in 2012 (Ukraina v 2013..., 2014). In 2014 Ukraine reduced the import of gas from Russia down to 14.5 bln cubic meters (which is 1.8 times less than in 2013), and increased import of gas from EU by 2.4 times (from 2.1 bln cubic meters to 5 bln cubic meters) (Ukraina v 2014..., 2015).

$75.5 \%$ of total potential hydrocarbon (gas and oil) resources is deposited overland, while $24.5 \%$ is on shelf of the Black and the Azov Seas. Ukraine takes the third place in Europe (after Great Britain and Norway, excluding Russia) by oil deposits, however, oil extraction is much less than in specified countries and many other European and non-European countries (State Geological and Mineral Resources of Ukraine, n.d.).

Extraction of natural gas and oil also decreased in 2014. As some of the sources of these resources are on the shelf of the Black and the Azov Seas, this was also influenced by the annexation of Crimea by the Russian Federation in 2014.

In 2014 the amount of consumed oil products was 5.6 times more than the amount of produced oil products. This relation increases with every year, despite the fact that Ukraine reduces the amount of consumed oil products annually: in 2014 the amount of consumed petroleum, diesel fuel and masut decreased by $15 \%$ compared to 2013 , and by $19 \%$ compared to 2012. The amount of produced petroleum, diesel fuel and masut was reduced in 2014 by $39 \%$ compared to 2013, and by 59\% compared to 2012 . 
Ukraine extracts about 500-800 tonnes of uranium annually, which provides only $30 \%$ of the country's atomic energy needs. The rest of the required uranium is imported mainly from Russia (Website on Nuclear and Radiation Safety and Non-Proliferation, n.d.; Pavlenko, 2014). Ukraine has 4 nuclear plants with 15 power generating units in Zaporizhzhya, Mykolayiv, Khmelnitsky, and Rivne, which today work at full capacity to provide the country with the necessary energy (World Nuclear Association, 2015, Nuclear Power in Ukraine). Ukraine has 12 assured uranium deposits, the resources of which can provide Ukrainian nuclear plants for 100 years. The biggest deposits are located in Kyrovograd region, which is in the centre of Ukraine (Website on Nuclear and Radiation Safety and NonProliferation, n.d.). However, there are problems with Ukrainian uranium ore's enrichment, storing and processing of waste products, maintenance and replacement of nuclear equipment and its component parts.

According to Energy Balance of Ukraine, in 2012 Ukraine also produced energy from alternative sources: wind and sun energy. The share of such energy sources in total energy resources is miserable - 53 thousand TOE compared to 122488 thousand TOE (total produced energy) (or $0,043 \%)$. Production of energy from biofuel and waste products was 1565 thousand TOE in 2012 (or 1.28\% from total produced energy) (State Statistics Service of Ukraine, 2013, Energetychnyi balans). State Agency on Energy Efficiency and Energy Saving of Ukraine says that "Ukraine has a considerable technically achievable potential to produce fuels from renewable energy sources and alternative fuels ... which is above 98,0 mln. tons per year" (State Agency on Energy Efficiency and Energy Saving of Ukraine, n.d., Potential). However, the total amount of energy produced from sustainable sources in 2013, could substitute only 200.4 thousand tons of fuel, which proves significant underload of Ukraine's capacities. Still, the amount of sustainable energy, produced in 2013, was 1.5 times more than the same indicator in 2012 (1144.9 thousand Gcal in 2013 compared to 382.9 thousand Gcal in 2012.) (State Agency on Energy Efficiency and Energy Saving of Ukraine, n.d., Suchasnyy stan).

The dynamics of capacity and production of electrical energy from sustainable sources in Ukraine (Table 3) shows that these indicators grow significantly every year. The total capacity of sustainable energy sources increased in 2013 by $83 \%$ compared to 2012 , and by $710 \%$ compared to 2010. The total production of electrical energy from sustainable sources increased in 2013 by $95 \%$ in relation to 2012 , and by $529 \%$ in relation to 2010. These sources are registered sources, which are of state and private property and have the right to use "green" tariffs for consumption of sustainable energy. 


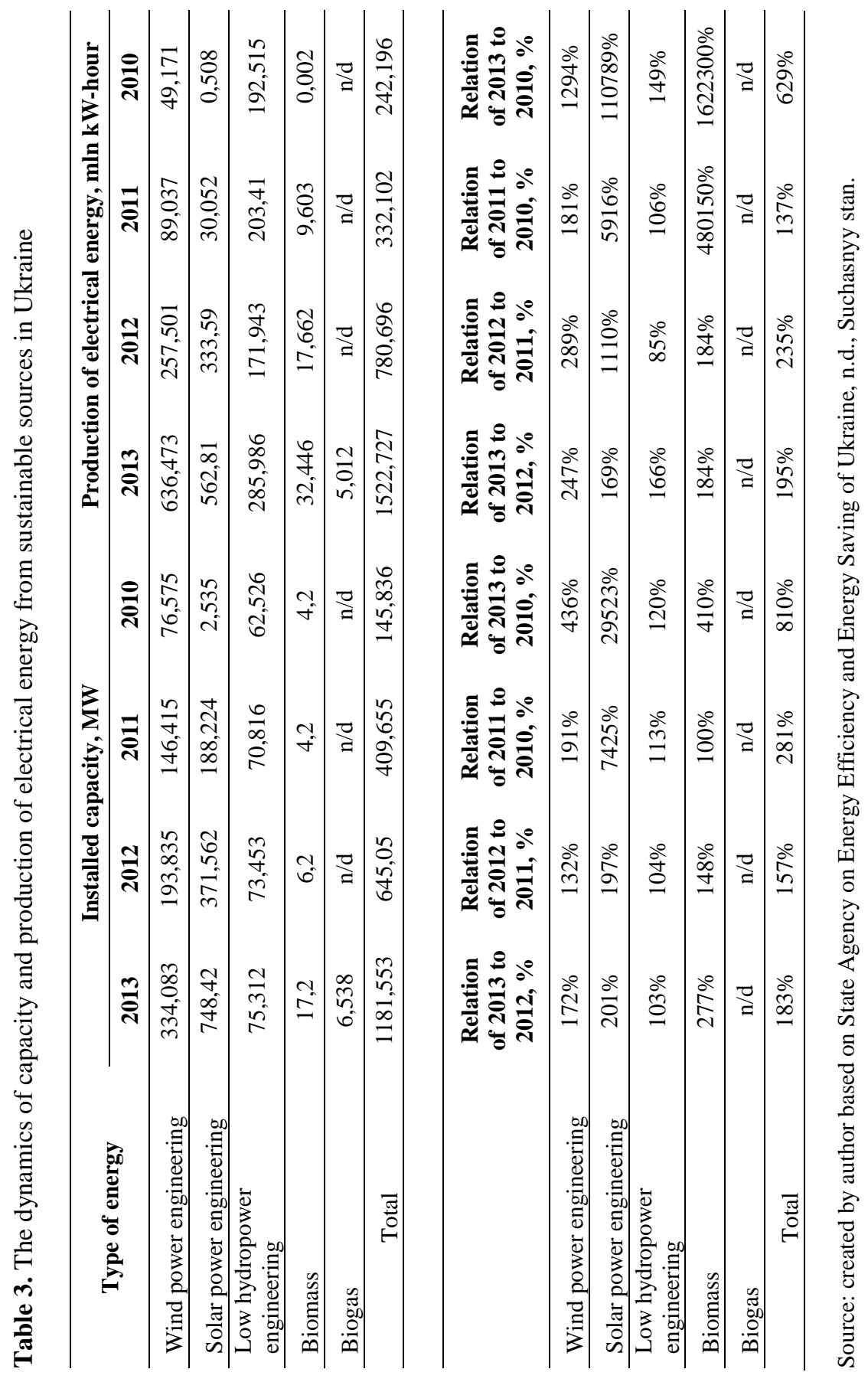


The increase of sustainable energy sources cannot acknowledge the strengthening of energy security of Ukraine, as, firstly, the share of sustainable energy sources in the total amount of sources is very small, and, secondly, some of the objects of sustainable energy sources are situated in Crimea ( 4 sun power stations and 1 wind power station, the delivery of energy from which was stopped in April 2014) and Luhansk region (1 wind power station), part of the territory of which is not under control by the Ukrainian government (State Agency on Energy Efficiency and Energy Saving of Ukraine, n.d., Suchasnyy stan).

Production of energy in Ukraine is decreasing against the increasing world energy production (Global Energy Statistical Yearbook 2011). However, the energy consumption in Ukraine remains high.

Energy efficiency of Ukrainian industries is backward and outdated, compared to other European countries. For example, energy costs reach $10 \%$ of all costs in metallurgical industry, and $40-70 \%$ in chemical industry (depending on the type of products). Besides, partial work load of many industrious companies influence quantity of energy costs, as they often make manufacturing overhead costs (Sukov \& Kabash, 2014).

Ukrainian industries are energy-wasteful. Despite the fact that energy intensity decreased significantly in Ukraine for the past 10 years, the country still has the leading positions in energy intensity of GDP among the world countries (Global Energy Statistical Yearbook 2011; Sukov \& Kabash, 2014). Primary energy use ( $\mathrm{kg}$ of oil equivalent per capita) in Ukraine was 2,884 in 2010, and 2,766 in 2011.

\section{Relation of Energy Sources and Energy Security of Ukraine to Sustainable Development}

Energy security and development of energy sector in a country are directly connected to all constituents of its sustainable development: economic, ecological and social. Provision of access to energy sources, improvement of energy consumption, increase of sustainable energy sources are the goals of UN Initiative "Sustainable Energy for all", which are planned to be reached by 2030 (United Nations, n.d.).

Developed energy sector and, as a result, stable energy security attest development and stable work of industries in a country, provision with necessary energy resources industries and household sector, and thus influence economic development of a country.

Economic development of a country is connected with income of population, availability of goods and services, purchasing power. Stable supply 
of energy for the needs of population reflects satisfaction of people's basic needs and rights, standards of living, social and human development of country's population.

Development of energy sector in a country may lead to environmental problems, as energy factories and plants are real and potential sources of pollution. As an example, the accident on Chernobyl atomic energy station in 1986 significantly influenced environment and people's health.

According to analyzed data (Tables 1-3), Ukraine's energy sources cannot be considered sustainable, as extraction of resources and industries' performance are accompanied by ecological and social problems, power loss, and resources waste.

Coal, being the most significant source for Ukrainian industries, is not a sustainable energy source. Coal mining is a source of the range of ecological problems in Ukraine, among which are the following: air pollution, change of geological, hydrological and hydrochemical state of the territories on which the coal producers operate (Ogarenko, 2007). Earth surface slump, underflooding, change of mesophytic plant formations, mineralization of water-bearing stratum and soil take place in the areas, where coal mines are situated. These changes lead to consequent damage of buildings, constructions and communications, make soil and water unsuitable for industrious, agricultural and household usage, pollution of water and change of species. Operation of coal mines and spontaneous combustion of ore residues emit carbon and sulphur dioxide, hydrogen sulphide, nitric oxide into atmosphere. The operation of coal-mines leads to annual emission of 5.6 bln cubic meters of methane into atmosphere. The most polluted regions in Ukraine are Luhansk, Donetsk, Dnepropetrovsk. One spontaneous combustion of disposals can emit 150 tonnes of carbon dioxide, 1.5 tonnes of sulphur dioxide, 0.4 tonnes of hydrogen sulphide, 0.1 tonnes of nitric oxide for 1 day into atmosphere (Osnovni Problemy..., 2002).

Coal industry has the leading position in traumatism and mortality among other industries in Ukraine. Every mined tonne of coal takes lives of 2 miners (for comparison 1.1 in Russia and 0.03 in the USA). Besides, there are a lot of illegal mines, which, first of all, lack safety engineering, secondly, illegally use labour force and underpay workers, thirdly, illegally extract the natural resources of Ukraine (Makogon, 2008).

Extraction of gas and oil is also connected with environmental and economic problems. The environmental effects of gas and oil extraction deal with water and soil pollution. Examination of pollution processes showed that about $60 \%$ of groundwater pollution is related to accidents in waste water run and drain and well-drilling, and more than $30 \%$ of pollution is related to defects and breakage of subsurface equipment. Soil and water 
pollution lead to health problems and increase governmental costs for relevant programs (Ekolohichni Problemy..., n.d.).

The possibility of shale gas extraction in Ukraine brought to heated discussions about the prospects and problems of using such resource. On the one hand, Ukraine has considerable shale gas storage, which can support the country's economic security and improve its independence from Russia. Besides, the source of gas will be closer to consumers than the imported gas, and thus will decrease the final costs for its transportation and usage. The exact amount of shale gas resources has not been defined yet: the range of possible values is between 1.2 and 7 trillion cubic meters. According to (Yakusheko \& Yakovlev, n.d.), Ukraine takes the $4^{\text {th }}$ place in Europe by available shale gas resources, being just after Poland, France and Norway. On the other hand, shale gas extraction requires advanced technologies installation, considerable investments, and has serious impact on state of environment. The main environmental consequences of shale gas development and extraction are an increase of seismic activity risks, groundwater, water, soil and air pollution (Barannik, n.d.).

Some countries banned specific technologies of shale gas extraction on their territories because of possible negative environmental effects, which will affect people's health and lives (Bonine et al., 2013). However, large scale extraction of shale gas can totally change the energy map of the world. This change acquires political and economic shade, and may neglect the potential ecological problems, related to shale gas extraction (Yakusheko \& Yakovlev, n.d.). Safety of technology for shale gas extraction is directly connected to its expenses. Thus, the extraction of shale gas in Ukraine should be carried out according to transparent principles and observance of all necessary safety measures.

Using atomic energy is always connected with risks for human lives and environment. One of the biggest environmental catastrophes in the whole world - the accident at Chernobyl atomic energy station - happened in Ukraine in 1986. The effects of the accident were enormous, as they irradiated thousands of people and contaminated the territories of Ukraine, Belarus, Russia, Scandinavia and parts of Europe (World Nuclear Association, 2014). The health effects were radiation sickness, rapid increase of cancer diseased (including thyroid cancer, leukaemia, etc.) among adults and children, cataracts, heart diseases, autoimmune thyroiditis and others (United Nations Scientific Committee on the Effects of Atomic Radiation, 2008).

Current environmental problems which are related to using atomic energy deal with nuclear waste processing. There are three types of waste, produced by Ukrainian atomic stations: gas-aerosol, thin and hard. They are processed according to specific for each type technologies (Website on 
Nuclear and Radiation Safety and Non-Proliferation, n.d., Povodzhennya). Ukraine also has some repositories for storing radioactive waste and certain amount of waste is sent back to Russia for reprocessing (World Nuclear Association, 2015). Management of radioactive waste requires significant costs, and needs constant improvement and modernization.

Non-productive and productive loss of energy and water is another problem of both: sustainability of energy sector and energy security. The loss leads to unjustified increase of energy tariffs and additional costs of the government (Tekhnichne pereosnashchennya..., n.d.).

Thus development of energy sector and energy security of the country are directly connected with its sustainable development. The interconnection of the three constituents are evident. On the one hand, development of sustainable energy sources in Ukraine is one of the important factors of strengthening energy security of the country. On the other hand, strengthening energy security of Ukraine provides the ways of further sustainable development of the country, its economy and society. Besides, development of energy sector is connected with increase of resources extraction, risks of environmental pollution and human health.

\section{Dependency of Ukrainian Energy Security, Threats and Ways Out}

Ukraine is not an energetically secure country. Despite the fact, that the country has all necessary resources for provision itself with necessary amount of energy, dependency of Ukrainian energy security on Russia remains significant. The reasons for energy insecurity are connected with the general problems of energy state in the country and its economic and political development.

The main threats for the energy security of Ukraine deal with external and internal factors. Internal factors are very close to the problems of other post-Soviet countries (Pluzhnik \& Saprykina, 2013). External factors deal with the old energy connections, established when Ukraine was a part of the Soviet Union. Some of the threats are:

- high depreciation and obsolescence of equipment and fixed capital stocks of power engineering objects. A lot of plants and factories still use old equipment or equipment, which is set up for processing only certain type of resources. Unsatisfactory state of equipment and other assets increases costs and energy intensity of fuel and energy resources (Kasich \& Yakovenko, 2013); 
- energy-wasteful economics of Ukraine. Despite the fact, that energy intensity decreased significantly in Ukraine for the past 10 years, the country still has the leading positions in energy intensity of GDP among the world countries (Global Energy Statistical Yearbook 2011, Sukov \& Kabash, 2014);

- unstable prices for imported gas and oil (Transatlantic energy..., 2014);

- absence of diversification of energy resources' import sources;

- current events in Ukraine: annexation of Crimea and antiterrorist operation in the East of the country.

The crisis in Ukraine undermined its energy security. Significant energy resources are situated on the occupied territory, which is not currently under control of the Ukrainian government. The electric stations suffer from coal deficit, as the coal was supplied from coal-mines from Donetsk and Luhansk regions. Ukraine continues to deliver coal from the occupied territories, but the deliveries are not stable, and the amount of coal is less than required (V Minenergo otchitalis..., 2015). The coal deficit led to power cut-offs all over Ukraine, and the necessity to import coal from other countries (Zapasy uglya..., 2015). However, the coal, imported to Ukraine from South Africa according to the recent treaties, does not have the necessary characteristics, and caused additional costs to Ukraine (Ukraina neset..., 2015).

Due to the current situation, Ukraine is also concerned with loss of potential gas deposits in Crimea and Donetsk region (shale gas deposits in Donetsk region, gas and oil deposits on Crimea peninsula) (The energy dimensions..., 2014; Korysni kopalyny..., n.d.).

The war conflict in Ukraine may lead to gas crisis not only in the country, but in Europe as well. According to NATO reviews (Transatlantic energy..., 2014; Russian-Ukrainian-EU..., 2014), Russian gas company Gazprom provided Ukraine with more than half of the gas it needed, and supplied more than 1/3 of EU imported gas. Half of the imported gas to EU is going through Ukraine, which can be threatened with the escalation of the conflict. Loss of control of certain areas by Ukraine creates possible risks to energy security of other European countries, as the gas pipelines pass through that territory (Carney, n.d.).Ukraine itself struggles with paying the increased prices for gas because of the economic crisis as a war's consequence.

The main document, which set the directions of energy sector development, is Energy Strategy of Ukraine on period till 2030. It was adopted by the Cabinet of Ministers of Ukraine in 2006 and was renewed several times later. In 2013 the new Energy Strategy of Ukraine on period till 2030 was adopted, which foresees satisfaction of energy needs of the country and 
strengthening its economic security taking into account environmental effects of energy sector operation. The document contains information on all energy resources, their extraction and usage, suggests measures on energy saving, increase of energy efficiency, increase of sustainable energy sources' share in total amount of energy needed. Prognostic energy balance on 2030 expects increase of all resources extraction (coal, oil, gas, production of heat and water energy). The amount of sustainable energy is expected to increase by 80 times in 2030, compared to 2010 (Cabinet of Ministers of Ukraine, 2013). However, a lot of regulations of the Strategy have declarative nature and require adoption of other documents and programs. The strategy itself did not take into account the possible crisis in 20142015, which is happening at the moment.

State Agency on Energy Efficiency and Energy Saving of Ukraine developed National Plan of Actions on Renewable Energy on period till 2020. The main goal of the Plan is to increase the renewable energy sources and make the share of renewable energy in total amount of consumed energy $11 \%$. The renewable energy sources, stipulated in the Plan, are biomass, wind energy station, sun photoelectrostations, geothermal energy, hydroelectric power stations (State Agency on Energy Efficiency and Energy Saving of Ukraine, n.d.).

There are also other programs and plans, which deal with the energy sector and the security of Ukraine. They are adopted locally in the cities or by enterprises and organizations (Stalyj energetychnyj..., n.d., DTEK, 2012). The measures, which are foreseen by all the programs (governmental and local) for strengthening of energy security of Ukraine (Kasich \& Yakovenko, 2013), are the following: switch to alternative energy sources and/or increase of their share in total sources of energy; modernization of gas, electrical and heat systems (which will decrease the amount of energy used); development of idle gas fields; breaking up the monopoly of the gas market.

It is very difficult at present to predict the reality of Ukrainian energy strategies and plans goals achievement. The numbers and calculations in the Strategy need revision, as energy production and consumption changed in the result of annexation of Crimea and loss of control of significant areas in the East of Ukraine (as coal industry, renewable energy plants, heavy industry plants and factories were situated there). Besides, the goals themselves require additional disclosure of operations and measures, which have to be implemented. Without such disclosure the goals seem more "declarative" than realistic. The main obstacles to realization of all mentioned programs and strategies are lack of investments and insufficient transparency of the projects, which can be performed to reach the goals. 


\section{Conclusions}

Energy security is an important issue for Ukraine's sustainable development. The main energy resources in Ukraine are: coal and peat, crude oil, oil products, natural gas, atomic energy, hydroenergy, wind and sun energy, biofuel and waste, electrical energy, and heat energy. Ukraine's energy sources cannot be considered sustainable, as extraction of resources and industries' performance are accompanied by ecological and social problems, power loss and resources waste.

Despite the fact that Ukraine has enough resources' deposits to provide itself with energy, the state of country's energy security is not satisfactory. Ukraine provides less than 50\% of own demands and is dependent on Russia's resources. There are other threats to the Ukrainian energy sector development, including current war situation and the need of restructuring.

The adopted Energy Strategy in Ukraine suggests the positive changes for the Ukrainian energy sector, but its realization is complicated with numerous external and internal factors. Structural reforms should be made in all directions of energy policy, which will help the country to resist the internal and external threats to its security. Any changes in the course of strengthening energy security of the country should be conformed to sustainable development concept regulations.

\section{References}

Barannik, V. (n.d.). Extraction of Shale Gas in Ukraine. Problems and Prospects. Analytical Report. National Institute for Strategic Studies. Retrieved from http://www.niss.gov.ua/articles/1304/.

Bonine, J., Kravchenko, O., \& Khomechko, G. (2013). Exploration and Extraction of Shale Gas: Social and Ecological Challenges (Brief Report). Lviv: International Charitable Organization "Ecology - Law - Human".

Cabinet of Ministers of Ukraine. (2013). Energy Strategy of Ukraine on Period Till 2030. (n0002120-13). Retrieved from http://zakon4.rada.gov.ua/laws/ show/n0002120-13.

Carney, S. (n.d.). Ukraine Rebels Threaten Europe's Energy Security, Says Czech PM. The Wall Street Journal. Retrieved from http://www.wsj.com/artic les/ukraine-rebels-threaten-europe-s-energy-security-says-czech-pm-1417101 950.

DTEK. (2012). Energy in Action. Annual Report 2012. Retrieved from http://www.dtek.com/library/file/annual-report-2012-en.pdf.

Ekolohichni Problemy Naftovydobuvnoyi Promyslovosti (n.d.). Retrieved from http://bukvar.su/jekologija/196045-Ekologicheskie-problemy-neftedobyvayush eiy-promyshlennosti.html. 
Global Energy Statistical Yearbook 2011 (2011). Retrieved from https://yearbook.enerdata.net/2010/2010-energy-primary-production.html.

Kasich, A., \& Yakovenko, Y. (2013). Gas Markets of EU and Ukraine: Current State and Prospects of Development. Business Inform, 9.

Korysni kopalyny Ukrayiny (n.d.). Retrieved from http://geoswit.ucoz.ru/index/0157.

Makogon, Y. (2008). Coal Industry of Ukraine: Problems and Prospects of Sustainable Development. National Institute for Strategic Studies. Retrieved from http://old.niss.gov.ua/Monitor/desember08/5.htm.

Ministry of Energetics and Coal Industry of Ukraine (2015). Statystychna informatsciya. Retrieved from http://mpe.kmu.gov.ua/minugol/control/uk/publish /officialcategory?cat_id=35081.

Oblasna programa rozvytku torfyanoyi galuzi "Torf Kyyivshchyny" na 2012-2015 roky. Proekt (2011). Retrieved from http://nadoest.com/programa-rozvitkutorfyanoyi-galuzi--torf-kiyivshini-na-2012-2.

Ogarenko, Y. (2007). Problems of Coal Industry of Ukraine and Emission of Greenhouse gases from Extraction and Consuming of Coal. Kyiv: National Ecology Center of Ukraine.

Osnovni Problemy Rozvytku Vuhil'noyi Haluzi i Rehionu Donbasu (2002). Kyiv: Donetsk Information Analytical Center, Center of Economic Development, Coal Consulting Center.

Pavlenko, E. (2014). Three Pillars of Reform of Ukrainian Energetic. Zerkalo nedeli. Retrieved from http://gazeta.zn.ua/energy_market/tri-stolpa-reformukrainskoy-energetiki-_.html.

Pluzhnik, M., \& Saprykina, M. (2013). Energy Security and Threats to Its Provision in Current Economy of Russia. Rossiyskoe predprinimatelstvo, 16(238).

Prognoznyye zapasy uglya v Ukraine - 117,5 mlrd. tonn, razvedannyye - 56,7 mlrd. tonn (2005). Ukrrudprom. Retrieved from http://www.ukrrudprom. com/news/nplachkov140505.html.

Russian-Ukrainian-EU Gas Conflict: Who Stands to Lose Most? (2014). NATO Review Magazine. Retrieved from http://www.nato.int/docu/review/2014 /NATO-Energy-security-running-on-empty/Ukrainian-conflict-Russia-annexat ion-of-Crimea/EN/index.htm.

SSIE "Geoinform Ukrainy". (n.d.). Mineral-raw Materials Base of Ukraine. Retrieved from http://www.geoinf.kiev.ua/msb.htm.

Stalyj energetychnyj rozvytok (n.d.). Retrieved from http://rada.dolyna.info/prioryt ety/enerhozberezhennya/.

State Agency on Energy Efficiency and Energy Saving of Ukraine. (n.d.). Potential. Retrieved from http://saee.gov.ua/en/activity/vidnovlyuvana-enerhetyka /potentsial.

State Agency on Energy Efficiency and Energy Saving of Ukraine. (n.d.). Suchasnyy stan. Retrieved from http://saee.gov.ua/uk/activity/vidnovlyuvanaenerhetyka/suchasny-stan. 
State Agency on Energy Efficiency and Energy Saving of Ukraine (n.d.). Nacionalnyj plan dij z vidnovlyuvanoyi energetyky na period do 2020 roku. Retrieved from http://saee.gov.ua/sites/default/files/documents/Presentation_N APRES _Norw_OCT_3_ukr.pdf.

State Geological and Mineral Resources of Ukraine (n.d.). Palyvno-energetychna syrovyna. Retrieved from http://www.geo.gov.ua/palivno-energetichnasirovina.html.

State Statistics Service of Ukraine (2013). Energetychnyi balans Ukrayiny za 2012 rik. Express release. Ukraine.

State Statistics Service of Ukraine (2013). Fuel and Energy Resources of Ukraine. Statistical Publication. Ukraine.

Sukov, A., \& Kabash, N. (2014). Energy Intensity of Ukrainian Economics Is the Highest in Europe. Capital. Retrieved form http://www.capital.u a/ru/publication/19016-energoemkost-ukrainskoy-ekonomiki-samaya-vysoka ya-v-evrope-industriya-khochet-modernizirovatsya.

Tekhnichne pereosnashchennya zhytlovo-komunal'noho hospodarstva, skorochennya pytomykh pokaznykiv vykorystannya enerhetychnykh $i$ material'nykh resursiv, pov'yazanykh z vyrobnytstvom zhytlovo-komunal'nykh posluh (n.d.). Retrieved from http://www.misto.esco.co.ua/best_practice/art50.htm.

The Energy Dimensions of Russia's Annexation of Crimea (2014). NATO Review Magazine. Retrieved from http://www.nato.int/docu/review/2014/NATOEnergy-security-running-on-empty/Ukraine-energy-independence-gas-depende nce-on-Russia/EN/index.htm.

Torf. (n.d.). Retrieved from http://gardenclub.net.ua/articles/5.

Transatlantic Energy Security and the Ukraine-crisis: A Blessing in Disguise? (2014). NATO Review Magazine. Retrieved from http://www.nato.int/docu /review/2014/NATO-Energy-security-running-on-em pty/Transatlantic-energysecurity-Ukraine-crisis/EN/index.htm.

Ukraina neset ogromnyie ubyitki iz-za afrikanskogo uglya (2015). Coal Portal of Ukraine. Retrieved from http://ukrcoal.com/news/ukraina-neset-ogromnyeubytki-iz-za-afrikanskogo-uglya.

Ukraina v 2013 godu importirovala gaza na 12 mlrd doll (2014). UNIAN. Information agency. Retrieved from http://economics.unian.net/energetics/876987ukraina-v-2013-godu-importirovala-gaza-na-12-mlrd-doll.html.

Ukraina v 2014 godu pochti v dva raza sokratila import gaza iz Rossii i uvelichila iz ES (2015). Mirror Weekly. Retrieved from http://zn.ua/ECONOMICS/ ukraina-v-2014-godu-pochti-v-dva-raza-sokratila-import-gaza-iz-rossii-i-uvelic hila-iz-es-164145_.html.

Ukrayina rozpochala promyslovyi vydobutok uranu (2011). Ukrayinska Pravda. Ekonomichna Pravda. Retrieved from http://www.epravda.com.ua/news /2011/06/30/290487/.

United Nations Scientific Committee on the Effects of Atomic Radiation (2008). Sources and Effects of Ionizing Radiation. (E.11.IX.3) 
United Nations (n.d.). 2012 International Year of Sustainable Energy for All. Retrieved from http://www.un.org/en/events/sustainableenergyforall/back ground.shtml.

V Minenergo otchitalis o postavkah uglya iz DNR i LNR (2015). LB.ua. Retrieved from http://economics.lb.ua/state/2015/01/05/291322_minenergo_otchitalis _postavkah.html.

Vydobutok vugillya v Ukrayini nyni vedetsya v 160 shahtah. Infografika (2013). Ukrinform. Retrieved from http://www.ukrinform.ua/ukr/news/vidobutok_ vugillya_v_ukraiini_nini_vedetsya_v_160_shahtah_infografika_1857135.

Website on Nuclear and Radiation Safety and Non-Proliferation. (n.d.). Retrieved from http://uatom.org/posts/29.

Website on Nuclear and Radiation Safety and Non-Proliferation. (n.d.). Retrieved from http://uatom.org/pages/57.

World Nuclear Association. (2014). Chernobyl Accident 1986. Retrieved from http://www.world-nuclear.org/info/Safety-and-Security/Safety-ofPlants/Chern obyl-Accident/.

World Nuclear Association. (2015). Nuclear Power in Ukraine. Retrieved from http://www.world-nuclear.org/info/Country-Profiles/Countries-T-Z/Ukraine/.

Yakusheko, L., \& Yakovlev, Y. (n.d.). Prospects of Extraction of Shale Gas in Ukraine: Ecological Aspects. National Institute for Strategic Studies. Retrieved from http://www.niss.gov.ua/content/articles/files/slanets-19b15.pdf.

Zapasy uglya na ukrainskih TES umenshayutsya (2015). Segodnia.ua. Retrieved from http://www.segodnya.ua/economics/enews/zapasy-uglya-na-ukrainskihtes-umenshayutsya-583469.html. 